\title{
Technological structures in construction during the implementation of the National Strategy for Sustainable Development - 2035
}

\author{
Ilya Maltsevich ${ }^{1}$
}

\begin{abstract}
:
Scientific and technical progress (STP) in construction leads to changes in engineering, technology, organization of construction, forms and methods of management of construction production. The role of scientific and technological progress is to find production reserves to reduce the time, labor intensity, cost of construction and improve quality by creating new and improving existing construction equipment and technologies, increasing mechanization and automation of production processes, creating and using new types of building materials and structures, mastering new and improvement of previously produced products and improvement of their quality. STP is the basis for the classification of production and has a decisive impact on all factors in the development of construction production. The purpose of the work is to draw up a structural and logical scheme for the development of construction, taking into account economic, environmental, social, innovative factors and the concept of technological structures in the development of construction. Results. The article considers the relevance of solving the problem of an accelerated transition of the construction industry of the Republic of Belarus to the sixth technological order, analyzes the most typical problems that have a negative impact on the process of changing structures, outlines the role of the National Sustainable Development Strategy - 2035 for solving this set of problems.
\end{abstract}

\section{KEYWORDS}

technological structures; construction; sustainable development

\section{Introduction}

The change in technological structures occurs on the basis of economic growth, which is the main component of social development and quality of life. The time lag, from an increase in macroeconomic indicators to an improvement in living standards felt by the majority of society, can be long. There is concern among academics about combining economic growth with increasing inequality, especially in the face of the competition between living labor and machines, automation and computer programs.

Therefore, the economic development of construction should contribute to the growth of income, their fair distribution based on increased labor productivity, and the creation of highly productive jobs. Scientific and technical progress in construction includes changes in technique, technology, organization of construction, forms and methods of management of construction production. Its role is to find production reserves to reduce time, labor intensity, construction costs and improve quality.

1 State Scientific Institution "Institute of Economics of the National Academy of Sciences of Belarus", Minsk, Republic of Belarus, e-mail: miv1995@mail.ru, orcid id: 0000-0003-0859-6235 


\section{Discussion}

The development of the economy is determined by the efficiency of resettlement of people, the development of labor mobility, the degree of readiness of workers, if necessary, to develop new territories or remain in place, when production is closed and their re-profiling is carried out. In all cases, the decisive role in this issue is played by the factor of housing, its availability, prospects for improvement, and an increase in the quality of services in the housing and utilities sector [1].

Housing acts both as a tool for creating conditions for the formation of a human resource, and as an end in itself within the framework of the implementation of the main priority of socioeconomic development - improving the quality of life of the population. This determines the importance of the housing and construction policy in the complex socio-economic development of the republic. As part of the economic effects of housing and construction policy, one can single out a general economic recovery due to an increase in the turnover of the construction industry, the development of banking and insurance services, which, as a rule, accompany housing construction, the development of infrastructure (transport, communication, educational, etc.), an increase in the revenue side of the budget, etc. [2].

The development of the construction industry leads to the revival of related industries (production of building materials, mechanical engineering, chemical industry, woodworking, etc.); positively affects the financial and credit system (through investment and credit channels); enhancing the functioning of the education system.

The analysis of social effects indicates that the implementation of housing construction policy contributes to the improvement of the quality of life: demographic growth, the development of labor mobility and the promotion of employment of the economically active population. Housing construction is one of the most important socio-economic subsystems, acting as an organized set of economic entities, objects and processes that ensure the construction of housing in order to meet the needs of the population of the territory for housing.

Economic growth reflects the dynamics of the economy without taking into account its complex structure, relationships, and the degree of balance. The key structural problem of growth is the proportionality of the growth rates of different types of economic activity. Economic development, in contrast to growth, is based on the positive dynamics of most types of economic activity, the formation of complete value chains. From this point of view, the current state of domestic construction does not meet the balance requirements. Its products and services are exported on various scales [3].

Construction is one of the key industries in the Republic of Belarus and determines the state of the economy and the solution of social problems. In the construction industry, there are more than 10 thousand contractors with more than 200 thousand employees [4].

The structural diagram of the construction development process, taking into account economic, environmental, social, innovative factors, is shown in Figure 1.

Construction is the most important sphere of the national economy, participating in the reproduction of fixed assets, the development and improvement of the social sphere, the reconstruction and modernization of the production of material goods. The share of construction in the structure of gross domestic product (GDP) is steadily increasing.

The main directions of technological development of construction are:

- introduction of new innovative technologies in construction, providing a resource-saving type of reproduction of construction products;

- development and implementation of energy - and resource-saving technologies for the construction of buildings and structures;

- development of the construction of monolithic residential buildings with the integrated use of permanent formwork from cement particle board;

- development of wooden housing construction;

- development and implementation of new Belarusian construction equipment, expansion of the range and increase in production of domestic machines and mechanisms, such as tower 
cranes, machinery and equipment for finishing and roofing works, units for applying fire retardant coatings, mini-plants for the production of lightweight foam concrete, replacing foreign analogues. This will increase labor productivity in construction and reduce import dependence in high-tech equipment;

- introduction of European standards for the design, construction and operation of housing, which will expand the development of comprehensive and mutually beneficial cooperation with the countries of the European Union and increase the export of construction work (services).

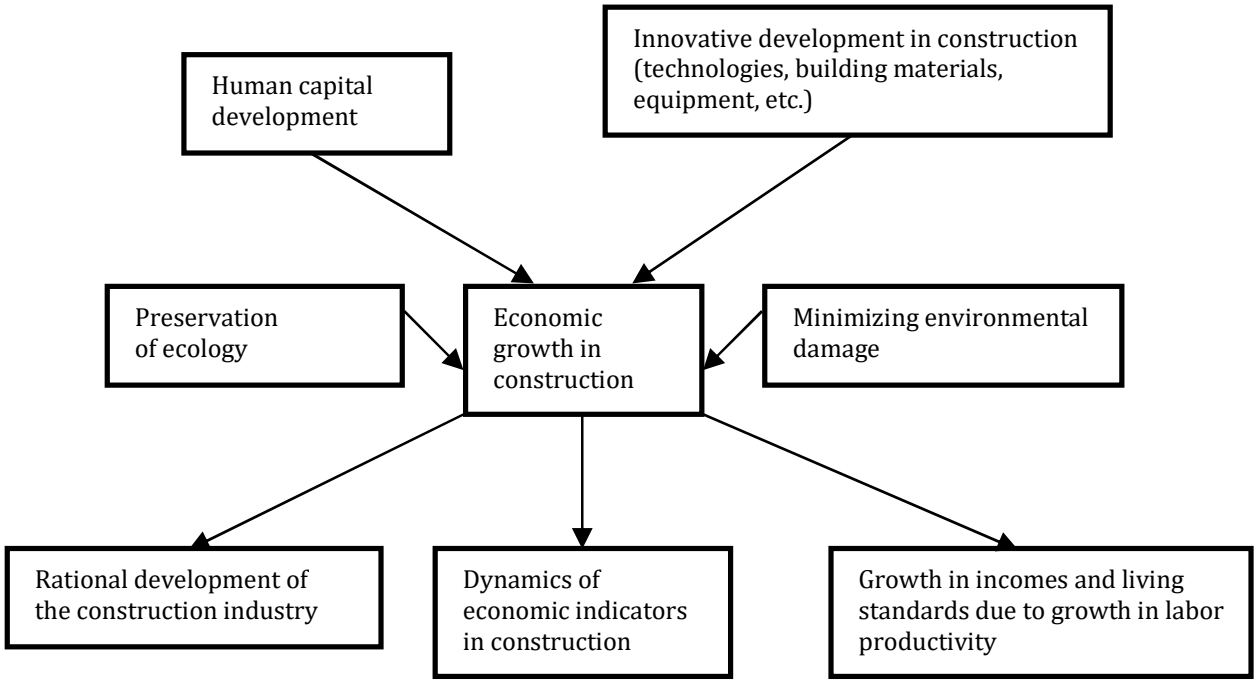

Fig. 1. Structural and logical diagram of construction development (source compiled by the author)

Based on the National Strategy for Sustainable Development (NSDS -2035) [5], the key directions and mechanisms for the development of construction are:

- development of energy efficient construction of commissioned multi-storey and individual residential buildings with high energy efficiency classes $\mathrm{A}+$ and $\mathrm{A}$;

- the creation of regular functioning structures that ensure the direct participation of civil society in urban planning and urban management;

Taking into account the decrease in the level of human resources in the construction sector of the Republic of Belarus, NSUR-2035 requires the introduction of a mechanism for comprehensive targeted training of specialists in construction specialties. Improving the conditions for remuneration of construction personnel in order to prevent their outflow:

- improving the financing mechanism for "green" construction through the introduction of "green" bonds, in order to implement environmentally friendly investment projects in construction;

- implementation of infrastructure investment projects aimed at new construction or modernization of facilities, on the principles of public-private partnership, ensuring high quality construction, low budget spending, fast design and construction of facilities;

- attracting foreign investment to create innovative technological capacities in construction;

- building up the export of construction services;

- development of a system of foreign trade support for construction activities, taking into account electronic document management and identification of products and services;

- increasing the efficiency of administrative procedures in construction based on obtaining a permit for design and construction, the implementation of the concept of "one window" and the creation of a unified database of requirements. 
Deviations from these directions are not desirable and can be considered as "growth without development".

Consequently, the content of the construction development process can be considered on the basis of innovative, social, environmental factors.

Insufficient technological level, limited diffusion of innovations are a problem for the development of the economy as a whole, however, in relation to construction, we have to talk about technological backwardness due to the level of development of productive forces. Therefore, further directions of development should be selected taking into account global trends and be focused on the concept of technological paradigms, characterized by a single technical and technological level of its constituent industries, connected by horizontal and vertical flows of qualitatively homogeneous resources based on common resources of scientific and technical potential, highly qualified labor force and other individual factors of the organization of the production process.

The study of publications by various scientists and researchers, as well as the systematization of these concepts for the development of the construction industry, allows us to identify the most significant and systemic problems that have a negative impact on the process of changing technological structures, which include: moral and physical deterioration of equipment and technologies reaching a critical level; a shortage of qualified personnel due to relatively low wages, a decline in the prestige of engineering and technical and working specialties, aggravation of social problems and a decrease in the total number of active population; lack of financial resources for the implementation of strategic transformation programs, including: the introduction of advanced management and organizational and technical solutions, the modernization of the production infrastructure, the training and attraction of qualified personnel, and the development of new competitive types of products.

The existing technological level of construction does not count on sustainable development in terms of economic, environmental and social parameters.

Over the past 20 years, science and technology in the Republic of Belarus have been intensively developed.

One of the promising directions in the study of the features of scientific and technological progress is the study of its influence on the formation of long-term trends in macroeconomic development [6, p. 53].

In modern conditions, scientific and technological progress is the basis of sustainable development, since the most important macroeconomic indicators are provided through the practical use of its achievements in the form of innovations. In the context of the transition to an innovative economy, the purpose of the functioning of any macroeconomic system is to ensure longterm sustainable economic growth, which is based on a change in technological structures [7, pp. 60-61].

Researchers of the innovation sphere S.Yu. Glazyev et al. identified only five technological modes [8, p. 95-111]. But with the development of science and technology, the sixth technological order was formed.

Scientific and technological progress and its role in the development of construction characterizes the concept of technological orders (Table 1).

As can be seen from the above data, most construction organizations belong to the third and fourth technological modes.

The third mode in construction involves the introduction of machines and the mechanization of technological processes while maintaining the cost of manual labor.

The fourth mode is the first "green revolution", where, in relation to machinery and equipment, the formation of uniform "end-to-end" technological processes with a minimum of logistic barriers and manual labor is taking place. This way of life was formed in 1930-1940, was the most progressive until 1980-1990.

The long-term prospects for the development of construction are associated with the fifth technological order, which makes it possible to overcome the problems of the fourth - high resource intensity and cost of construction, deterioration of the environmental situation. 
Table 1

Technological paradigms and the main source of growth in construction compiled by the author on the basis of $[8,9]$

\begin{tabular}{|c|c|c|c|c|c|}
\hline $\begin{array}{l}\text { Techno- } \\
\text { logical } \\
\text { order }\end{array}$ & $\begin{array}{l}\text { Dominance } \\
\text { period, } \\
\text { years }\end{array}$ & $\begin{array}{l}\text { Leading } \\
\text { countries }\end{array}$ & $\begin{array}{l}\text { The core of the } \\
\text { technological } \\
\text { order }\end{array}$ & Organization of production & $\begin{array}{l}\text { The main source } \\
\text { of growth }\end{array}$ \\
\hline 1 & $1770-1830$ & $\begin{array}{l}\text { England, } \\
\text { France, } \\
\text { Belgium }\end{array}$ & $\begin{array}{l}\text { Construction of } \\
\text { main canals }\end{array}$ & Production modernization & $\begin{array}{l}\text { Muscle power, } \\
\text { water engine, } \\
\text { wind power }\end{array}$ \\
\hline 2 & $1840-1880$ & $\begin{array}{l}\text { France, } \\
\text { Belgium, } \\
\text { USA, } \\
\text { Germany }\end{array}$ & $\begin{array}{l}\text { Railway and } \\
\text { steamship } \\
\text { transport, } \\
\text { mechanical } \\
\text { engineering, } \\
\text { improvement of } \\
\text { metal processing } \\
\text { processes } \\
\end{array}$ & $\begin{array}{l}\text { The role of scale production } \\
\text { based on mechanization (rapid } \\
\text { development of railway } \\
\text { construction) }\end{array}$ & $\begin{array}{l}\text { Steam engine, } \\
\text { metallurgy, } \\
\text { railways, internal } \\
\text { combustion } \\
\text { engine, conveyor }\end{array}$ \\
\hline 3 & $1890-1940$ & \begin{tabular}{|l} 
England, \\
France, \\
USA, \\
Germany, \\
Belgium, \\
Netherlands, \\
Switzerland
\end{tabular} & 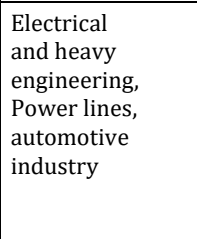 & $\begin{array}{l}\text { Increase in the variety and } \\
\text { flexibility of production, increase } \\
\text { in product quality, standardization, } \\
\text { urbanization. feature - the wide- } \\
\text { spread use of electric motors and } \\
\text { the rapid development of electrical } \\
\text { engineering, the construction of } \\
\text { power plants }\end{array}$ & $\begin{array}{l}\text { Ferrous metallurgy, } \\
\text { electricity, } \\
\text { chemistry, } \\
\text { telecommunications, } \\
\text { automotive }\end{array}$ \\
\hline 4 & $1950-1980$ & $\begin{array}{l}\text { EEC countries, } \\
\text { Australia, } \\
\text { Canada, } \\
\text { Japan }\end{array}$ & $\begin{array}{l}\text { Mechanical } \\
\text { engineering, } \\
\text { electronic } \\
\text { industry }\end{array}$ & $\begin{array}{l}\text { Mass production of serial products, } \\
\text { further standardization of produc- } \\
\text { tion, conveyors. } \\
\text { The formation of the automotive } \\
\text { industry and the development of the } \\
\text { first samples of tracked transport } \\
\text { and special equipment. This stage } \\
\text { is characterized by a new machine } \\
\text { base, comprehensive mechanization } \\
\text { of production, automation of } \\
\text { technological processes, the use of } \\
\text { skilled labor, an increase } \\
\text { in production specialization }\end{array}$ & $\begin{array}{l}\text { Wide and fast spread } \\
\text { of processes }\end{array}$ \\
\hline 5 & $\begin{array}{l}1990 \\
\text { before } \\
2035\end{array}$ & $\begin{array}{l}\text { EEC countries, } \\
\text { Germany, } \\
\text { Sweden, } \\
\text { Australia, } \\
\text { Taiwan, } \\
\text { South Korea, } \\
\text { Sweden }\end{array}$ & $\begin{array}{l}\text { Gas } \\
\text { technologies }\end{array}$ & $\begin{array}{l}\text { A combination of large enterprises } \\
\text { with small businesses. } \\
\text { Development of information and } \\
\text { communication technologies. } \\
\text { Improvement of new machines } \\
\text { and equipment (computers, } \\
\text { robots, processing centers, various } \\
\text { automatic machines), and infor- } \\
\text { mation systems (databases, local } \\
\text { and integrated computing systems, } \\
\text { information languages and software } \\
\text { for information processing). } \\
\text { Flexible automation of industrial } \\
\text { production dramatically expands } \\
\text { the variety of products. }\end{array}$ & $\begin{array}{l}\text { Gas technologies, } \\
\text { computers, } \\
\text { electronics, } \\
\text { nuclear energy }\end{array}$ \\
\hline 6 & \begin{tabular}{|l|} 
Early \\
$2025-2030 s-$ \\
$2035-2040 s$ \\
years
\end{tabular} & & $\begin{array}{l}\text { Nanotechnology, } \\
\text { genetic } \\
\text { engineering } \\
\text { and cell } \\
\text { technologies, } \\
\text { artificial } \\
\text { intelligence, } \\
\text { additive } \\
\text { technologies }\end{array}$ & $\begin{array}{l}\text { Its key areas include biotechnology, } \\
\text { artificial intelligence, CALS-techno- } \\
\text { logies, global information networks } \\
\text { and integrated high-speed } \\
\text { transport systems, computer } \\
\text { education, the formation of } \\
\text { networked business communities. } \\
\text { Increasing robotization production, } \\
\text { Needs society in highly qualified } \\
\text { cited workers, emergence new } \\
\text { types professions }\end{array}$ & $\begin{array}{l}\text { NBIC - technologies, } \\
\text { 3D - printers, drones, } \\
\text { Internet of things, } \\
\text { etc. }\end{array}$ \\
\hline
\end{tabular}


The fifth structure in construction emerged in the late 1980s - early 1990s. and will be distributed until 2035. It involves the use of global technological trends (electronics, automation, information technology, nano-biotechnology, unmanned aircraft). Within the framework of the fifth structure, an integrated management system for a construction organization and technical processes is being formed. It is based on precise digital technology, automation, with minimal resource costs and environmental stress.

It is assumed that the sixth technological mode in construction will begin its development in the 2025-2030s. and will displace the fifth order as less progressive by the 2035-2040s. However, this is a long-term task, even abroad.

\section{Conclusions}

The structural and logical diagram of the development of construction given in the work, taking into account economic, environmental, social, innovative factors, makes it possible to single out the most characteristic factors affecting the economic growth of construction.

In modern conditions, scientific and technological progress is the basis of sustainable development, since the most important macroeconomic indicators are provided through the practical use of its achievements in the form of innovations. In the context of the transition to an innovative economy, the purpose of the functioning of any macroeconomic system is to ensure longterm sustainable economic growth, which is based on a change in technological structures in the development of construction.

\section{References}

[1] Morozova T.G., Pobedina M.P., Polyak G.B. and other, Regional economy: textbook for Universities, Ed. prof. T.G. Morozova, 3rd ed., Rev. and add., UNITI-DANA, M .: 2011.

[2] Rakovsky V.I., Slepukhina I.L. Housing construction: problems, prospects, ways of development, Economics and Management 2012, 7, 31-35.

[3] On the priority directions of development of the construction industry: Directive of the President of the Republic of Belarus, March 04, 2019, No. 8, ConsultantPlus Belarus: [Electronic resource] / YurSpektr LLC., Minsk 2020.

[4] Concept of the National Strategy for Sustainable Development until 2035: [Electronic resource]. Access mode: https://rovar.info/koncepcija-nacionalnoj-strategii-ustojchivogo-razvitija-respubliki-belarus-na-period-do2035-goda/, Access date 21.08.2021.

[5] Cycles of capital reproduction: monograph, S.N. Kozmenko, T.A. Vasilyeva, I.D. Sklyar and others - Sumy: Business prospects, 2005.

[6] Daderkina E.A., Baynev V.F. Scientific and technological progress and sustainable development: theory and practice of useful (use-value) assessment of the effectiveness of new technology, [Text], [monograph], under the total. ed. V.F. Baineva, Law and Economics, Minsk 2008.

[7] Glazyev S.Yu. The theory of long-term technical and economic development. - M .: VlaDar, 1993.

[8] Technological structure [Electronic resource]. Access mode: https://vuzlit.ru/706301/tehnologicheskiy uklad - Access date 20.08.2021.

[9] Historical stages of development of building houses: [Electronic resource]. Access mode: https://dom-srubbanya.ru/istoricheskie-etapy-razvitiya-stroitelstva-domov/ Access date 20.08.2021.

\section{Postęp technologiczny w budownictwie podczas wprowadzania Narodowej Strategii Zrównoważonego Rozwoju - 2035}

\section{STRESZCZENIE:}

Postęp naukowo-techniczny w budownictwie prowadzi do zmian w: inżynierii, technologii, organizacji, konstrukcji, formach i metodach zarządzania produkcją budowlaną. Rolą postępu naukowo-technicznego jest znajdowanie rezerw produkcyjnych w celu skrócenia czasu, zmniejszenia pracochłonności, kosztów budowy oraz poprawy jakości. Wymienione korzyści można uzyskać poprzez: tworzenie nowych i ulepszanie istniejących urządzeń i technologii budowlanych, zwiększanie mechanizacji i automatyzacji procesów produkcyjnych, tworzenie i stosowanie nowych typów materiałów i konstrukcji budowlanych, opanowanie 
nowych i doskonalenie wcześniej wytworzonych wyrobów oraz podnoszenie ich jakości. Postęp naukowo-techniczny jest podstawą klasyfikacji produkcji i ma decydujący wpływ na wszystkie czynniki rozwoju produkcji budowlanej. Celem pracy jest opracowanie schematu strukturalnego i logicznego rozwoju budownictwa, uwzględniającego czynniki ekonomiczne, środowiskowe, społeczne, innowacyjne oraz koncepcję struktur technologicznych w rozwoju budownictwa. Artykuł rozważa zasadność rozwiązania problemu przyspieszonego przejścia branży budowlanej Republiki Białorusi do szóstego porządku technologicznego, analizuje najbardziej typowe problemy, które mają negatywny wpływ na proces zmiany struktur, nakreśla rolę Narodowej Strategii Zrównoważonego Rozwoju - 2035 w rozwiązaniu ww. problemów.

\section{SŁOWA KLUCZOWE:}

struktury technologiczne; budownictwo; zrównoważony rozwój 